\title{
Translation of Binomials in Hard News: A Contrastive Study of English and Persian
}

\author{
Shima Hejazi \\ Department of English, Shahreza Branch, Islamic Azad University, Shahreza, Iran \\ Shima.2011hejazi@yahoo.com \\ Hossein Vahid Dastjerdi
}

Corresponding Author, Department of English, Shahreza Branch, Islamic Azad University, Shahreza, Iran

Email: h_vahid@yahoo.com

\section{Doi:10.5901/mjss.2015.v6n2s1p512}

\section{Abstract}

This study was an attempt to appraise the naturalness of translated binomials in hard news and to recognize the most frequently-used translation strategies in this respect. To this purpose, the researchers used Vinay and Darbelnet's (1958) categorization of strategies as the model of study. The obtained results showed that the most frequently-used strategies are respectively as follows: "Literal translation", "Modulation", "Transposition", "Loan translation" (borrowing), and "Calque". "Adaptation" was not used in this research by the participants. Also, males used "Literal translation" more than "Modulation" possibly because of their background knowledge and their interest in hard news, while females used "Modulation" more than "Literal translation" because of their psychological and emotional attitudes towards hard news.

Keywords: binomials, collocations, hard news, conjunctions, naturalness, modulation, reduplication

\section{Introduction}

According to Akbari (2013), translation has assumed a significant role in interdisciplinary fields such as medicine, engineering, law, and literature. Translation is a means of transferring the correct content of the source language into the target one and vice versa. But, the important note, he adds, is how the translator can transmit the intended information and content in the right direction and how the renderer can create the same feeling of the translated text into the target audience. It is the duty of translators to transfer the meaning from the SL to TL according to the cultural items and transfer the meaning clearly. As an example, translators should know how to translate binomials and collocations in a text and try to use correct equivalents for them in English and Persian. This is due to the fact that, collocation clashes put binomial expressions into danger and it causes untranslatability in this connection. The present research is therefore specifically pertained to hard news and binomial items. So, finding strategies to translate binomials appropriately is very important. Thus, the rationale behind focusing on this study stemmed from the condition that naturalness of binomials plays a key role in hard news translation.

\subsection{Purpose of the Study}

Binomials are language specific phenomena. Only few studies have been done on translation of binomials. The present study aimed at examining the Persian translation of English binomials in hard news. Based on Vinay and Darbelnet's model (1958) researchers provided the most frequent strategies for translating binomials. These strategies will be useful for reporters, TV announcers, and interviewers.

\subsection{Research Questions}

Based on what was stated above, the present study addressed the following three questions:

1) To what extent do Persian translators observe the use of binomials in hard news?

2) What translation strategies do translators utilize to transfer English binomials into Persian effectively?

3) Does participants' gender play any role in translating hard news binominals? 


\section{Background of the Study}

A brief glance at the literature of the field reveals that studies on binomials are very limited and puts many research lacunas for the investigation of its translation in different genres and different languages. All speakers of English use sequences of words such as 'all in all', 'again and again', 'before or after', 'control and discipline', 'fair and true' in their everyday speech. Nonetheless, ordinary speakers are not aware that they commonly use expressions in linguistic sphere known as binomials, binomial expressions or doublets. Binomials term coined by Yakov Malkiel(1959) is defined as "a sequence of two words pertaining to the same form-class, placed on an identical level of syntactic hierarchy, and ordinarily connected by some kind of lexical link". Gustafsson (1975:9). Gustafsson further explains that a binomial consists of two members which are in parallel relation to one another. She distinguishes between irreversible binomials, if the order is fixed, and reversible ones, if it is not. (Gustafsson, 1975: 9). Another distinction is made between formulaic and unformulaic binomials, the difference defined as "the former are permanent and fixed combinations in the language, while the latter are temporary but fill the semantic and syntactic requirements". (Gustafsson, 1975: 9) .There is other expressions referring to or used in connection with the term of binomials. In linguistic studies words like repetition and intensification may be found. In a general sense, some do not cover all cases of binomials; on the other hand binomials are considered "only one of the several phenomena of intensification". Even various modifications of word pair also appear paired words, repetitive word pairs or twin formula (the German term in translation). Another term that appears is that of alliterative phrase found in a study of the alliterative poetry in early English. At last, Gustafsson (1975: 10) relates another linguistic aspect to the term. Carvalho (2008) attempted to provide necessary guidelines for rendering a natural translation in the genre of legal agreements. He found out that Brazilian translator in dealing with binomials "tends to translates all the elements of binomial literary", and therefore, "fail to attain the intended legal effect of the communicative event". She claims that binomials are a "distinct mark of legal discourse and extremely common in legal English" as Mellinkoff (1963) and Crystal and Davy (1969) put it, but also because there are many different kinds of binomials meaning that they represent a challenge to the legal translator (Asensio, 2003: 96-7; Kwok, 2000:3). Moreover, binomial expressions are not easily found in bilingual legal dictionaries. (Carvalho, 2006: 316). There are different researches on the translation of binomials in legal texts that shows the best strategies for translating binomials in legal texts. Different scholars have scrutinized binomials from pure linguistics perspectives. They attempted to find the rationale behind the existing alignment of conjuncts. They propose some constraints which could describe the order of conjuncts of binomials. Among the most prominent constraints we can name phonological constraints (Malkiel, 1959, Bolinger, 1962, Cooper and Ross, 1975), semantic constraints (Malkiel, 1959, Cooper and Ross, 1975, McDonald, 1993, Muller, 1997), and pragmatic constraints (Benor, S.B. 2006, Fenk-Oczlon, 1989). There are different constraints in translation of binomials and different experts have studied binomials and find a rationale behind binomials and conjunctions. Therefore, it is the translator's task to find the best strategy for translating binomials.

\subsection{Role of gender in translating hard news binominals}

Language and gender are connected to each other through the individuals' participation in the daily social relationships. Researches prove that males and females' languages are different (Holmes, 1995). In the 1990s translation studies saw a renewed interest in the analysis of gender and ideology in relation to, and interacting with, translation as theory and practice. Simon (1996) presented an extensive study of translation influenced by feminist thought, investigated gender issues in translation, and explored the ways in which women translators have been cultural mediators for centuries, creating "new lines of cultural communication" (Simon, 1996); and defines gender as an element of identity and experience which forms through social consciousness like the other cultural identities (Simon, 1996). Von Flotow (1997) researched practices of feminist translation, from the processes of 'gendered translation' to the translation of ideologically hostile texts, as well as the recovery of 'lost' women translators of the past. Their studies, among those of many other scholars, explored translation(s) operating within language and power. As Chamberlain (1998) states: "the issues relating to gender in the practice of translation are numerous according to the type of text, the language, cultural practices and countless other factors". Women's attendance in society was low in the past and it seemed they were not ever seen, but today women believe that they differ from men psychologically, emotionally, mentally, culturally and in many other aspects (Coates, 1997). A lot of studies exist regarding the role of gender as an index of language use. As Stockwell (2002) mentions today the concept of "genderlect" points to the various grammatical and vocabulary choices related to males and females. The role of the male and female participants in answering the questions showed that males used more "Literal translation" because of their background knowledge of hard news and also their interest to listen to hard news. Females used more "Modulation" because of their psychological and emotional attitudes towards hard news. 


\section{Methodology}

\subsection{Corpus}

The corpus for this study were 200 available binomials in hard news that the researchers selected, put into a questionnaire and provided their translation based on Vinay and Darbelnet's model (1958). Only 28 English binomials were put into questionnaire based on their meaning. The data were selected from among 200 binomials in hard news.

\subsection{Research instruments}

A researcher-made questionnaire was used in this study. It consisted of 28 binomials selected from among 200 binomials in hard news. Each question was followed by 3 choices, with only one of them being correct.

\subsection{Participants}

Frothy three first semester MA students of translation at Islamic Azad university of Shahreza served as participants in this study.

\subsection{Model of the study}

For the purposes of this study, the model proposed by Vinay and Darbelnet (1958) was exploited. This model introduces the following strategies to achieve natural equivalence: direct translation ("Borrowing", "Calque", and "Literal translation"), and oblique translation ("Transposition", "Modulation", "Equivalence", and "Adaptation").

\subsection{Procedures}

In collecting data, the researchers tried to use different kinds of binomials in hard news found in the book News and Media published in (2006). This book consists of 30 news lessons and English new words by definitions and audio scripts. The researchers studied the news precisely, chose 200 binomials and presented their meanings based on Vinay and Darbelnet (1958). Only 28 of binomials were put into the questionnaire with three alternatives. To discover the best strategies for translating English binomials into Persian existing in hard news, the following steps were taken: first, 200 English binomials in hard news were selected from the book News and Media. Only 28 of the binomials and their translation were put into the questionnaire. Second, the corresponding Persian translations of all 28 English binomials were identified. Third, the translated binomial expressions were given 43 M.A first semester students of translation to find the translation for each binomial in hard news.

\section{Analysis of Data}

As mentioned above, 43 first semester students of translation were selected. They were asked to answer 28 questions (See Appendix). Then their responses were analyzed. For each question the researchers presented separated tables. The most frequent strategies used by the participants are mentioned in the following tables.

Table 4.1. Distribution of strategies applied for translating binomials in hard news.

(Questions 1 to 28)

\begin{tabular}{|c|c|}
\hline Strategy & Frequency \\
\hline Literal translation & 659 \\
\hline Modulation & 429 \\
\hline Adaptation & 0 \\
\hline Transposition & 68 \\
\hline Loan translation (borrowing) & 33 \\
\hline Calque & 7 \\
\hline Total & 1196 \\
\hline
\end{tabular}


As table 4.1 shows, the most frequently-applied strategy is "Literal translation". The next strategy is "Modulation". "Transposition" is used 68 times. "Loan translation" (borrowing) is used 33 times and "Calque" is used 7 times. "Adaptation" is not used at all. The total frequency is 1196.

Table 4.2. Distribution of different kinds of modulations based on Vinay and Darbelnet (1958)

\begin{tabular}{|c|c|}
\hline Modulation & Frequency \\
\hline Part to whole or whole to part & 4 \\
\hline Negative to positive & 2 \\
\hline Abstract to concrete & 1 \\
\hline Reversal of items & 9 \\
\hline Dilution (amplification) & 8 \\
\hline Rethinking of limits & 2 \\
\hline Borrowing & 2 \\
\hline Change of symbols & 1 \\
\hline Singular for plural & 4 \\
\hline Negation of opposite & 4 \\
\hline Explication & 11 \\
\hline Active for passive & 3 \\
\hline Cause and effect & 2 \\
\hline Total & 53 \\
\hline
\end{tabular}

As table 4.2.shows, different types of modulation are used in questions 1 to 28 . The most frequently-used "Modulation" is "Explication" (used 11times). "Reversal of items" is used 9 times. The result shows "Modulation" is the most frequentlyused strategy in this research after "Literal translation".

Table 4.3. Frequency of male / female use of translation strategies

\begin{tabular}{|c|c|c|}
\hline Strategy & male & female \\
\hline Literal translation & 218 & 326 \\
\hline modulation & 212 & 386 \\
\hline
\end{tabular}

As it is shown in the above table, the male and female participants' frequency of use for "Literal translation" and "Modulation" strategies are respectively 218, 212 and 326, 386.

\section{Results}

The above tables show that the number of applied strategies is not equal. Actually, the most frequent strategy in all the tables is "Literal translation", the next most frequent is "Modulation", and other strategies are respectively "Transposition" and "Loan translation" (borrowing), and "Calque". "Adaptation", as mentioned before, has not been made use of. Also, the answers of male and female participants to the questions reveal that males have been inclined more towards "Literal translation", possibly because of their background knowledge of hard news and also their interest to listen to hard news. Females have, on the other hand, used "Modulation" more frequently, possibly because of their psychological and emotional attitudes towards translation of binomials in hard news.

\section{Discussion and Concluding Remark}

Persian translators observe binomials in hard news a lot because of usage of binomials in hard news and their importance for translators, teachers of translation, language learners, training courses, teaching translation methods, techniques, and also their translation from English into Persian. As tables and figures of the previous chapter show "Literal translation" was the most frequently-used strategy (659 times). "Modulation" was used 429 times. "Transposition" was used 68 times. "Loan translation" (borrowing) was used 33 times. "Calque" was used 7 times. "Adaptation" was not used at all in this study by the participants. In connection with the third research question, males used more "Literal translation" than females, while female participants used more "Modulation" than males. Based on these results, it is to be noted here that to gain the intended hard news effect, the translation must follow the principles of the target language. 
Lack of this shows why the participants do not have enough creativity for the translation of hard news binomials, which in turn leads them to using literal translation as the most frequent strategy. Besides, using modulation and explicitation (as the subcategory of modulation) is possibly due to the fact that in English the rule for making a sentence is subject + verb + object (SVO), while in Persian it is subject + object + verb (SOV). Adaptation has not been employed by the participants because the selected binominals are geographical and cultural items not used in hard news. These findings are in line with Carvalho's (2008) research in which the researcher provided necessary guidelines for legal agreements and found that the Brazilian translators tend to translate all the elements of binomials in a literal way. Another research which is in line with the present study is that of Gorgis and Al-Tamimi (2005) in which the researchers have investigated the order of conjuncts of binomials and similarities and differences in translation of binomials as related to cultural background and have concluded that the translator must be familiar with cultural items of SL and TL. Also, the present research is in line with Simon (1996) in which the author defines gender as an element of identity and experience which forms thorough social consciousness like other cultural identities. According to Coates (1997), women believe that they differ from men psychologically, emotionally, mentally, and culturally. Stockwell (2002) mentions that today the concept of "genderlect" points to the various grammatical and vocabulary choices related to males and females. Therefore, in the translation of binomials in hard news males used "Literal translation" more than "Modulation" because they may be more interested in hard news and may have background knowledge of politics and hard news, while females used "Modulation" more than "Literal translation" because they may have less background knowledge of hard news and politics and, possibly, due to their physiological and emotional attitudes towards hard news. The concluding remark is that since "Literal translation" won the first position as the most-frequently applied procedure in this study as in other similar studies, and since "Literal translation" is "a prescription for good translation" as Munday (2001:57) puts it, it should be considered significant by the translators of such constructs as binominals, especially in text types like hard news.

\section{References}

Akbari, A. R. (2013). Exploring into the New Model Procedure in Translation: Wafting as a Case in Point, International Journal of Education and Literary Studies, 1, 19-20.

Asensio, A. R. (2003). Translating Official Documents. Manchester and Northampton: St. Jerome.

Benor, S. \& Levy, R. (2006).The chicken or the egg? A probabilistic analysis of English binomials.Language 82 (2), $233-278$.

Bolinger, D. (1962). Binomials and pitch accent.Lingua 11.34-44.

Carvalho, L. (2006). OsDicionáriosJurídicosBilíngües e o Tradutor: doisbinômiosemdireitocontratual. Tradterm 12. São Paulo: Humanitas. 309347.

Carvalho, L. (2008). Translating Contracts and Agreements: a Corpus Linguistics Perspective. CulturasJuridias, 3, 1, 1-15.

Chamberlain, L. (1998). Gender Metaphorics in Translation.In M. backer (Ed.) Encyclopedia of Ttranslation Studies. London: Routledge.

Coates, J. (1997). Women, Men and Language (A Sociolinguistic Account of Gender Differences in Language).2nd Edition. London and New York: Longman.

Cooper, W. \& Ross, J. (1975). World order. Papers from the parasessionon functionalism, ed. by R. Grossman, L.J. San, and T. Vance, 63-111. Chicago:Chicago Linguistic Society.

Crystal, D. \& Derek, D. (1969). Investigating English Style.Bloomington: Indiana University Press.

Fenk-Oczlon, G. (1989). Word frequency and word order in freezes.Linguistics27.517-556.

Gorgis, D. T. \& Al-Tamimi, Y. (2005). Binomials in Iraqi and Jordanian Arabic.Journal of Language and Linguistics, 4, 2, $135-151$.

Gustafsson, M. (1975). Some Syntactic Properties of English Law Language.PublicationNo. 4. Turku, Finland: University of Turku, Department of English.

Gustafsson, M.(1975). Binomial Expressions in Present-day English: a Syntactic and Semantic Study. Turku: TurunYliopisto.

Holmes, J. (1995). Women, Men and Politeness. London and New York: Longman.

Kwok, W. H. (2000). Some Linguistic Devices in Legal English that Cause Problems to the Translation of Legislative Texts from English to Chinese. MacArthur, University ofWestern Sydney. [Master's thesis].

Malkiel, Y. (1959)."Studies in irreversible binomials".Lingua.8, 113-160.Definition of irreversible binomial in English (Oxford dictionary).

McDonald, J. L. \& Bock, K. \& Kelly, M. (1993). Word and world order: Semantic, phonological, and metrical determinants of serial position. CognitivePsychology 25.188230.

Mellinkoff, D. (1963). The Language of the Law. Boston: Little, Brown \& Co.

Mellinkoff, D. (1963). The Language of the Law. Eugene: Resource Publications.

Müller, G. (1997). Beschrankungen fur BinomialbildungenimDeutschen. ZeitschriftfurSprachwissenschaft16, 1/2.5-51.

Munday, J. (2001/2008). Introducing Translation Studies. Theories and Application, London, New York: Routledge.

Simon, S. (1996). Gender in Translation.Cultural Identity and the Politics of Transmission. London and New York: Routledge.

Stockwell, P. (2002). Sociolinguistics: A Resource Book for Students. London and New York: Routledge.

Vinay, J.P.\& Darbelnet, J. (1958). Stylistiquecomparée du françaiset de l'anglais.Paris, Didier.

Vinay, J.P. \& Darbelnet,J. (1958). StylistiqueComparée du Françaiset de l'Anglais: Méthode de Traduction. Paris: Didier.

Vinay, J.P. \& Darbelnet, J. (1958/1977). Stylistiquecomparee du francaiset de l'anglais(rev. edn). Paris: Les Editions Didier.

Von Flotow, L. (1997). Translation and Gender: Translating in the 'Era of Feminism'. Manchester: St. Jerome Publishing. 